\title{
Study of Edible Spontaneous Herbs in the Republic of Moldova for Ensuring a Sustainable Food System
}

\author{
Rodica Siminiuc ${ }^{*}$, Dinu Țurcanu² \\ ${ }^{1}$ Department of Food and Nutrition, Faculty of Food Technology, Technical University of Moldova, Chisinau, Republic of Moldova \\ ${ }^{2}$ Informatization, Partnerships, Institutional Image and Communication Office, Technical University of Moldova, Chisinau, \\ Republic of Moldova \\ Email: ^rodica.siminiuc@adm.utm.md, dinu.turcanu@adm.utm.md
}

How to cite this paper: Siminiuc, R. and Țurcanu, D. (2021) Study of Edible Spontaneous Herbs in the Republic of Moldova for Ensuring a Sustainable Food System. Food and Nutrition Sciences, 12, 703-718. https://doi.org/10.4236/fns.2021.127053

Received: June 8, 2021

Accepted: July 11, 2021

Published: July 14, 2021

Copyright $\odot 2021$ by author(s) and Scientific Research Publishing Inc. This work is licensed under the Creative Commons Attribution International License (CC BY 4.0).

http://creativecommons.org/licenses/by/4.0/

\begin{abstract}
Recent studies have shown that food systems fail to provide a healthy diet and are unfair and ecologically unsustainable. Sustainable food production will require multidisciplinary approaches, in which human, animal, and environmental health, are inextricably linked. There are various researches that make edible spontaneous herbs (ESP) the protagonists of a new trend in food approach, focused more on health, food safety, and connection with nature. The research consisted of the analysis and capitalization of (ESH) from the territory of the Republic of Moldova (RM) by reviewing their traditional use in local gastronomy and describing the nutritional characteristics. Ethnographic research techniques, such as conversations and interviews, were used to identify knowledge about the use of ESH in the RM. The use, phytochemical profile, and curative effects of the analyzed ESH were taken from the online database Plants For A Future (PFAF) and the phytochemical and ethnobotanical database of the US Department of Agriculture and Agricultural Research. The analysis of the specialized literature on ESH consumption in the world showed that their culinary application in the RM could still be diversified. Some of their properties could possibly be used in the design of new products for people with special diets.
\end{abstract}

\section{Keywords}

Ethnobotany, Edible Spontaneous Herbs, Phytonutrients, Sustainable Development, Republic of Moldova

\section{Introduction}

Although it is believed that the current global food system is able to provide ca- 
lorific value to the population, there are still an imposingly large number of people facing the double burden of malnutrition, where malnutrition coexists with overweight, obesity, and other diet-related diseases. The number of people suffering from hunger has reached 60 million in 2019. Preliminary estimates COVID-19 pandemic has accelerated this growth: adding another 132 million people in 2020 [1]. It is assumed that the world community will not be able to end hunger, food insecurity, and malnutrition in all its forms by 2030 [2]. Addressing these challenges would involve an increase in global food production, which cannot be achieved by simply expanding industrial agriculture which will lead to land conversion to the detriment of the environment and, consequently, an even more drastic reduction in biodiversity [3].

The rapid reduction of biodiversity limits the possibilities of finding new food sources [4], probably given that most research does not reflect information on the full spectrum of food resources consumed worldwide. Sustainable food production and environmental management are essential and will require multidisciplinary approaches, in which human, animal, and environmental health, are inextricably linked.

The benefits of using underutilized traditional crops and exploring more sustainable production methods for growing common crops are widely promoted [5] [6]. In this context, the conservation of diversity, the use of traditional food knowledge, information, and the development of associated policies, scientifically argued, are not only required but also become a global priority [7].

From ancient times, plant species have been essential for nutrition and still represent today more than $80 \%$ of the components of the daily diet. Many plants are consumed only locally, collected in nature, constituting a biological and cultural heritage of spontaneous edible species, which deserves to be appreciated for the benefit of all. The growing interest in the ESP has led many researchers to gather and disseminate local knowledge in order to preserve their traditions. There are various researches that make ESP the protagonists of a new trend in food approach, focusing more on health, food safety, and connection with nature [8].

In addition to being available, tasty, and easy to cook, ESP also has a high nutraceutical value consisting of a significant content of minerals and bioactive components that bring benefits to human health [9] due to the content of polyphenols and fatty acids [10]. It has been shown that, compared to many cultivated species, they have a higher fiber content [11], are rich in antioxidants and flavonoids and their beneficial effects have been proven in the prevention of various chronic diseases of modern society [12] [13]. After a period of abandonment, today in Europe interest in ESH is growing, enjoying well-deserved attention and recognition, helping to increase attention and consideration for ethnobotany and traditions related to the perception of nature as an environment of particular importance and important constituent of intangible cultural heritage [14]. Return-ing to traditional knowledge and flavors and appreciating 
local natural resources is an incentive for a commitment to building an ecosustainable world.

Aim of the study: The research consists of the analysis and capitalization of spontaneous edible herbs from the territory of the Republic of Moldova by reviewing their traditional use in local gastronomy and describing nutritional characteristics.

\section{Working Procedure}

The research was initiated within the state project, personalized nutrition and intelligent technologies for my well-being, carried out within the Technical University of Moldova. Ethnographic research techniques, such as conversations and interviews, were used to identify knowledge of the traditional use of ESH. Initially, conversations were held with students and masters of academic groups in the specialty of Technology and management in public catering (age $20-24$ years). Subsequently, the students were given the task to talk to other people from the place of birth (parents, grandmother, relatives, etc.). In total, the students interviewed about 120 people, over the age of 40 (40 - 80 years). The majority (about $80 \%$ ) of those interviewed were women.

As a result of the conversations and the interview, 16 ESH were selected and analyzed in the paper, which were mentioned at least once by the informants in the discussions. The fields, the use, the phytochemical profile, as well as the curative effects of the analyzed ESH were taken from two electronic databases: the online database Plants for A Future (PFAF), which contains information about over 8000 plants [15] and Dr. Duke's Phytochemical and Ethnobotanical Database, U.S. Department of Agriculture, and Agricultural Research Service [16].

To assess and compare the overall diversity of the analyzed ESHs, we used the data set "World Checklist of Useful Plant Species", produced by Royal Botanic Gardens, Kew [17]. This data set includes 40,292 species and was compiled by compiling plant uses and reconciling species names using the taxonomic backbone of Kew's Plants of the World Online portal [18].

Data on the knowledge of these herbs in the RM and how to use them were collected from conversations and interviews with informants.

\section{General Considerations: About RM}

The Republic of Moldova is a small country, located in southeastern Europe between Romania and Ukraine (Figure 1), covering an area of 3,384,300 ha. The relief is mostly hilly (Figure 2) with a maximum altitude of $429.5 \mathrm{~m}$.

The vegetal diversity of the Republic of Moldova is conditioned by the geographical position, topographic characteristics and climate. In Moldova, agroforestry biodiversity is dominant. The spontaneous flora of the Republic of Moldova currently includes over 1891 species of vascular plants [19]. Located at the crossroads of many historical roads, the culinary traditions of Moldovans have often been formed by force, due to wars, invasions or political and demographic 


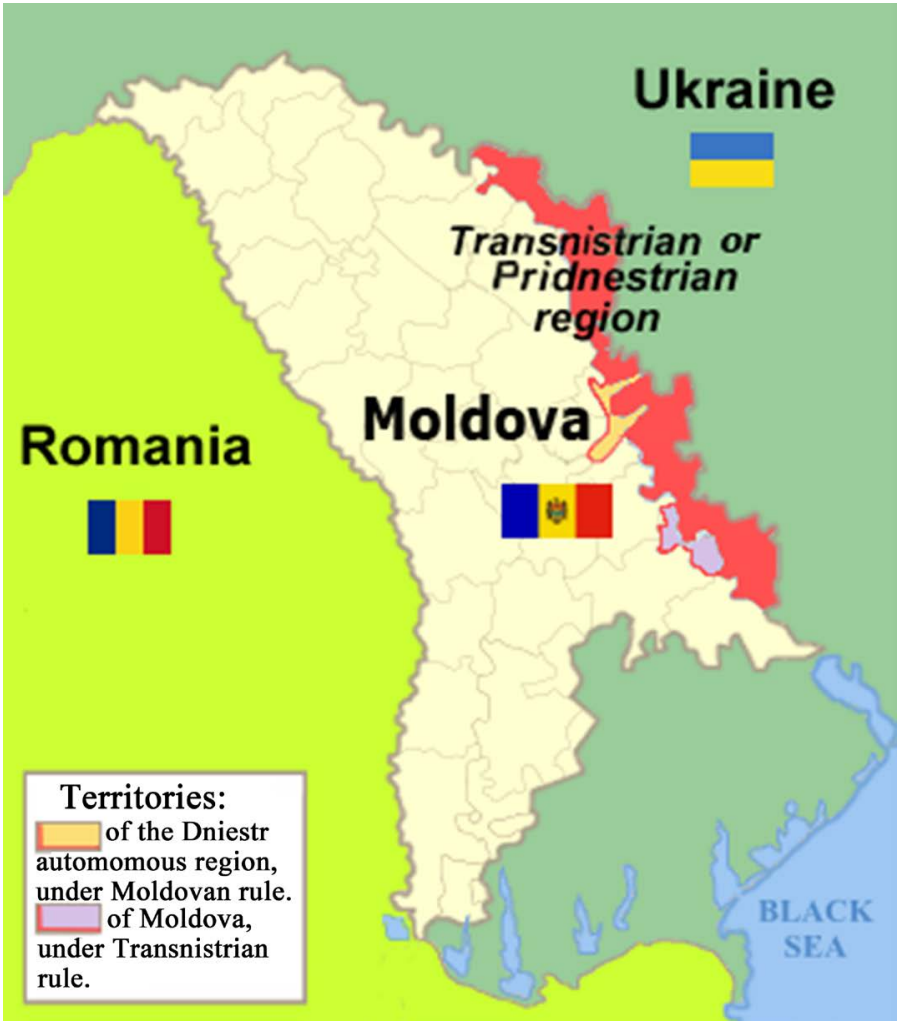

Figure 1. Map of Moldova.

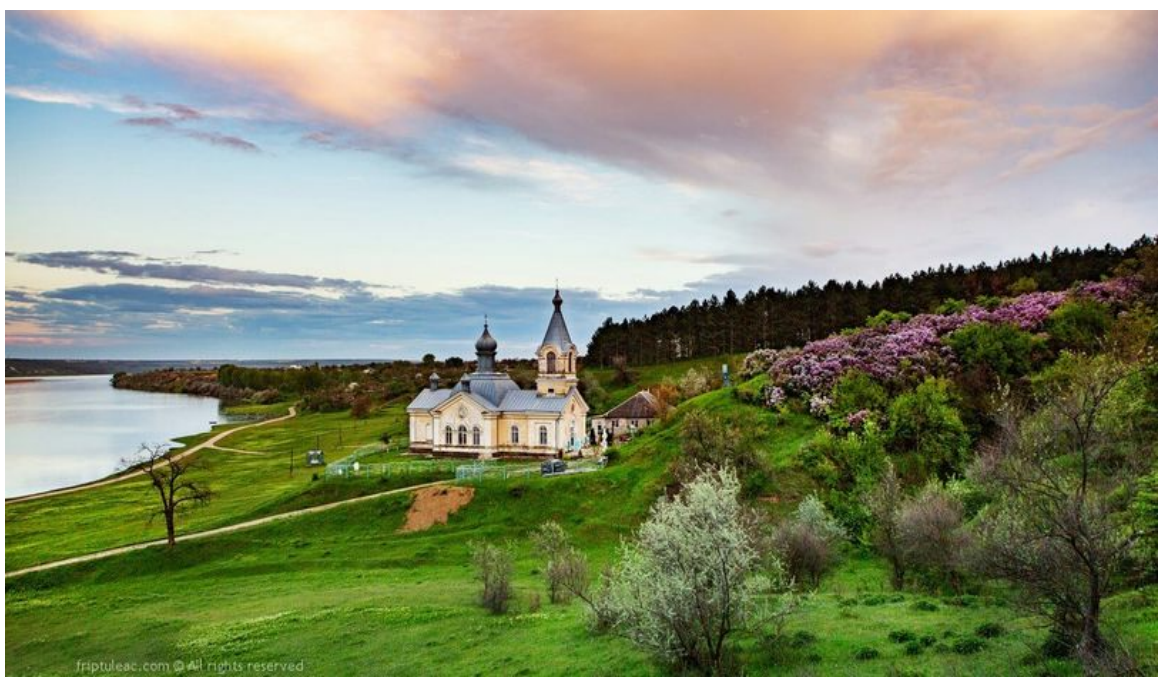

Figure 2. Rural image (Lopatna locality. Republic of Moldova).

changes. To meet the challenges, the natives, over time, found alternatives, using plants available as valuable allies for food and physical and spiritual well-being (Orthodox fasts having its logic not only religious but also expressing popular experience and wisdom).

The consumption of spontaneous plants (SP) was born without an evocative or romantic connotation, but purely utilitarian, dictated by the urgent need to feed, even in more difficult times. 
Hunger, drought, and wars, these are just a few reasons that have forced and still force people to look for alternative food resources, while appreciating the generosity of nature. Although these reasons are characteristic of many peoples and nations, it seems that for the Moldovan people the impact of those times was stronger with an echo that is still felt: the food shortage in Soviet Moldova in the first years after World War II, caused by a terrible drought, an extremely repressive totalitarian political regime, as well as the ruin of peasant households as a result of military hostilities, led to the compromise of a large part of the 1946 harvest [20]. The terrible famine forced the inhabitants of the country to resort to the practical consumption of all herbs, more or less edible. Some witnesses say that even the ground bark of trees is being consumed.

Various studies showed that ESH consumption is still seen as something related to poverty and nutritional deficiencies, in addition to poor livelihoods, while being considered part of traditional diets [21].

Today, the consumption of PS enjoys a well-deserved rebirth, this is largely due to global food trends. The collection of SPs from their natural environment has gained popularity, as people prefer quality products of known origin and enjoy direct contact with nature and the activity itself. So, for many, the motivation for collecting wild plants has shifted from the need to meet various essential needs to the preference for quality products and the pleasure of collecting. These motivations denote a positive self-perception and a personal commitment to the collection of plants from the wild [14]. Another cause of the growing popularity of ESP is due to the mass migration of Moldovans in search of a better existence (since the $90 \mathrm{~s}$ ). It has contributed to the diversification of the gastronomic heritage due to the takeover of new ingredients and culinary recipes, including ESP. The big paradox is that a large part of those ESPs brought to the country as new and fashionable plants, proved to be consumed since ancient times by the Bessarabians, only that their knowledge was forgotten with industrialization, with the abandonment of the rural environment and the beginning of food distribution chains.

It is considered that the main reason why SP consumption has decreased recently is their low availability, lifestyle changes, time constraints and limited knowledge of their nutritional value, scope and use.

\section{Results and Discussions}

Being a small country, the collection and consumption of spontaneous plants in the Republic of Moldova, however, differs not only from region to region, but also from village to village, varying depending on the natural environments they meet, the plant species that grow, but also by local traditions. And if in many countries' meals are omitted by choice and not by necessity, for some Moldovans, especially during the pandemic period, the search, collection and consumption of spontaneous plants for gastronomic use has taken on very different meanings than those mentioned above. 
As a result of conversations and interviews, a fairly large number of ESPs were mentioned, used on the territory of the Republic of Moldova now or in the past: from grasses, to shrubs to trees.

In order to achieve a deeper approach to the research topic, we focused on a narrower field-(ESH) [22]. Plants that do not synthesize or accumulate lignin are called grasses or herbaceous, also called herbs [23]. The FAO defines edible plants in spontaneous flora as "plants that grow and regenerate spontaneously, in natural or semi-natural ecosystems and can exist independently of human action".

\subsection{Knowledge of ESH in the RM and Their Usability in Human Nutrition}

\subsubsection{Discussions with Students}

As a result of conversations with students, the following were identified:

Among the most used ESH in food consumption and mentioned by students were Urtica dioica L., Rumex acetosa L., Thymus serpyllum, Papaver rhoeas L., Sonchus oleraceus, Taraxacum officinale L. Young people had more thorough knowledge of ESP, considered in vogue, as they are seen as attractive gastronomic resources for modern culinary experiences. Many restaurants in the country already include wild plants in their menus.

\subsubsection{Discussions with Parents, Grandparents and People from the Village}

As a geographical area, the interview covered practically the entire territory of the country. From the students' testimonies, it seems that the discussions with the respondents were marked by 2 major positive aspects:

1) Students have discovered new things about the consumption and use of ESH.

2) The people interviewed by the students (these being their parents, grandparents, natives from rural localities) remembered many ESHs that were once consumed in the country, but which, for various reasons, were forgotten).

In general, the results of the conversations can be summarized as:

- Older people (over 40 years old) still have knowledge about ESH used in the diet of Moldovans since time immemorial.

- From the multitude of mentioned ESPs were selected only ESH used in the diet of the natives (Table 1).

- The respective plants have been mentioned as being used both in human nutrition and for medicinal purposes.

- The interviewees confessed that the consumption of spontaneous herbs, at the current stage, is mainly due to the need to follow a curative diet and less often to nostalgia to return to traditional cuisine. This is explained by the fact that most of these spontaneous herbs, for a large part of the interviewees, have a sad utilitarian connotation, associated with poverty and need, dictated by the urgent need for food in times of famine in the postwar period (19461947). 
Table 1. Nutritional value and areas of use of ESH.

\begin{tabular}{|c|c|c|c|c|c|c|}
\hline & \multirow[t]{2}{*}{$\begin{array}{l}\text { Binomial } \\
\text { name }\end{array}$} & \multirow[t]{2}{*}{ Nutritional value } & \multirow[t]{2}{*}{$\begin{array}{l}\text { Areas of use } \\
\text { [17] [18] }\end{array}$} & $\begin{array}{l}\text { Edible } \\
\text { rating }\end{array}$ & $\begin{array}{l}\text { Medicinal } \\
\text { rating }\end{array}$ & Medicinal Uses \\
\hline & & & & \multicolumn{3}{|l|}{ [15] [17] } \\
\hline 1. & $\begin{array}{l}\text { Borago } \\
\text { officinalis } \mathrm{L} .\end{array}$ & $\begin{array}{l}\text { The leaves are rich in fatty acids, phenolic acids, } \\
\text { pyrrolizidine alkaloids and sterols, in mineral elements: } \\
\text { potassium and calcium [24] [25]. The seeds produce } 30 \% \\
\text { oil, of which } 20 \% \text { is gamma-linolenic acid. }\end{array}$ & $\begin{array}{l}\text { EU, GS, HF, } \\
\text { IF, MA, ME, } \\
\text { PO }\end{array}$ & 3 & 3 & $\begin{array}{l}\text { Antirheumatic, demulcent, } \\
\text { depurative, diaphoretic, } \\
\text { diuretic, emollient, } \\
\text { expectorant, febrifuge, } \\
\text { hypertensive soothing, } \\
\text { poultice, sensitive skin. }\end{array}$ \\
\hline 2. & $\begin{array}{l}\text { Cichorium } \\
\text { intybus } \mathrm{L} .\end{array}$ & $\begin{array}{l}\text { Rich in dietary fiber, carbohydrates, potassium, calcium, } \\
\text { magnesium, sodium, copper, zinc, manganese, iron and } \\
\text { vitamin A [26]. } \\
\text { Chicory root is a concentrated combination of three sugars } \\
\text { (pentose, levulose and dextrose) together with taraxacum } \\
\text { (the bitter principle of dandelion). It is especially important } \\
\text { as a source of levulose. }\end{array}$ & $\begin{array}{l}\text { AF, GS, HF, } \\
\text { ME, PO, SU }\end{array}$ & 4 & 3 & $\begin{array}{l}\text { Appetizer, bach, cardiac, } \\
\text { cholagogue, depurative, } \\
\text { digestive, diuretic, } \\
\text { hypoglycemic, laxative, } \\
\text { tonic, warts. }\end{array}$ \\
\hline 3. & $\begin{array}{l}\text { Malva } \\
\text { sylvestris } \mathrm{L} .\end{array}$ & $\begin{array}{l}\text { Contains flavonoids, tannins, saponins, alkaloids, } \\
\text { hemodolias, sterols and steroids, etc. [27]. }\end{array}$ & $\begin{array}{l}\text { EU, HF, MA, } \\
\text { ME, PO }\end{array}$ & 3 & 3 & $\begin{array}{l}\text { Antiphlogistic, astringent, } \\
\text { demulcent, diuretic, } \\
\text { emollient, expectorant, } \\
\text { laxative. }\end{array}$ \\
\hline 4. & $\begin{array}{l}\text { Papaver } \\
\text { rhoeas } \mathrm{L} \text {. }\end{array}$ & $\begin{array}{l}\text { Rich in flavonoids and flavones. Alkaloids, sodium, } \\
\text { potassium, magnesium, calcium. Amino acids, } \\
\text { carbohydrates, organic acids, phenolic compounds and } \\
\text { flavonoids [28]. }\end{array}$ & $\begin{array}{l}\text { EU, HF, ME, } \\
\text { PO }\end{array}$ & 2 & 3 & $\begin{array}{l}\text { Anodyne, cancer, } \\
\text { emmenagogue, emollient, } \\
\text { expectorant, hypnotic, } \\
\text { sedative, tonic. }\end{array}$ \\
\hline 5. & $\begin{array}{l}\text { Portulaca } \\
\text { oleracea L. }\end{array}$ & $\begin{array}{l}\text { Source of omega- } 3 \text { fatty acids, phenolic compounds, } \\
\text { oleracein derivatives, tocopherols (especially in the leaves) } \\
\text { sugars (glucose and fructose), oxalic acid and fatty acids } \\
\text { (palmitic acid and linoleic acid-strain) [29]. }\end{array}$ & $\begin{array}{l}\text { AF, EU, GS, } \\
\text { HF, MA, } \\
\text { ME, PO, SU }\end{array}$ & 4 & 3 & $\begin{array}{l}\text { Antiscorbutic, depurative, } \\
\text { diuretic, febrifuge, } \\
\text { vermifuge, skin, tonic. }\end{array}$ \\
\hline 6. & $\begin{array}{l}\text { Rumex } \\
\text { acetosa L. }\end{array}$ & $\begin{array}{l}\text { Contains vitamins A, C, K, E, B, proteins, tannins, fiber, } \\
\text { phenolic acids (gallic, ellagic acid, protocatechuic acid, } \\
\text { ferulic acid, p-coumaric acid, rosmarinic, vanillic, } \\
\text { synaptic). Pro anthocyanidins are epicatechin and } \\
\text { epicatechin derivatives, oxalic acid [30] [31]. }\end{array}$ & $\begin{array}{l}\mathrm{HF}, \mathrm{MA} \\
\mathrm{ME}, \mathrm{PO}\end{array}$ & 5 & 3 & $\begin{array}{l}\text { Anthelmintic, } \\
\text { antiscorbutic, astringent, } \\
\text { depurative, diuretic, } \\
\text { febrifuge, homeopathy, } \\
\text { laxative, refrigerant, } \\
\text { stomachic. }\end{array}$ \\
\hline 7. & $\begin{array}{l}\text { Taraxacum } \\
\text { officinale } \mathrm{L} .\end{array}$ & $\begin{array}{l}\text { Contains sugars, organic acids, fatty acids and tocopherols. } \\
\text { The flowers are rich in sugars, tocopherols and flavonoids } \\
\text { (mainly luteolin, oxhezide and luteolin) [32] [33]. Source of } \\
\text { calcium, phosphorus, iron, sodium, potassium, magnesium, } \\
\text { vitamin A, vitamin B1, vitamin B2, vitamin C. }\end{array}$ & HF, IF, ME & 4 & 3 & $\begin{array}{l}\text { Aperient, cholagoue, } \\
\text { depurative, diuretic, } \\
\text { hepatic, hypoglycaemic, } \\
\text { laxative, miscellany, } \\
\text { stomachic, tonic, warts. }\end{array}$ \\
\hline 8. & $\begin{array}{l}\text { Urtica dioica } \\
\text { L. }\end{array}$ & $\begin{array}{l}\text { Rich in polysaccharides, vitamins ( } \beta \text {-carotene), iron, } \\
\text { potassium, manganese, calcium, silicon, phosphate and } \\
\text { vitamin C. Its leaves contain a large amount of essential } \\
\text { fatty acids, such as } \alpha \text {-linolenic acid and linoleic acid, } \\
\text { essential amino acids and carbohydrates, carotenoids that } \\
\text { include Omega- } 6 \text { fatty acids, lutein, } \beta \text {-carotene. } 75 \% \text { of the } \\
\text { total chlorophyll content is } \alpha \text {-chlorophyll and } 25 \% \\
\beta \text {-chlorophyll [34]. }\end{array}$ & $\begin{array}{l}\text { AF, GS, HF, } \\
\text { MA, ME, } \\
\text { PO, SU }\end{array}$ & 5 & 5 & $\begin{array}{l}\text { Antiasthmatic, } \\
\text { antidandruff, } \\
\text { antirheumatic, } \\
\text { antiseborrheic, astringent, } \\
\text { diuretic, galactogogue, } \\
\text { haemostatic, hypoglycemic, } \\
\text { stings, tonic. }\end{array}$ \\
\hline 9. & $\begin{array}{l}\text { Tussilago } \\
\text { farfara L. }\end{array}$ & $\begin{array}{l}\text { Contains biologically active substances, polysaccharides } \\
\text { (fructose, galactose, arabinose, glucose, xylose and uronic, } \\
\text { acids, mucus (up to } 7 \% \text { - 10\%), saponins, carotenoids, } \\
\text { ascorbic acid, gallic acid, flavonoids, tannins, organic acids } \\
\text { (malic, tartar) [35]. }\end{array}$ & $\begin{array}{l}\text { HF, IF, ME, } \\
\text { PO }\end{array}$ & 3 & 3 & $\begin{array}{l}\text { Antitussive, astringent, } \\
\text { bitter, demulcent, } \\
\text { diaphoretic, emollient, } \\
\text { expectorant, skin, } \\
\text { stimulant, tonic. }\end{array}$ \\
\hline
\end{tabular}




\section{Continued}

10. Viola odorata Viola odorata contains flavonoids, phenols, alkaloids, L. glycosides, saponins, stigmasterols, methyl salicylate, mucilage and vitamin $C$, etc. [36].

11. Lamium album $\mathrm{L}$. A wide range of constituents is found in L. album, including flavonoids and phenolic acids, fatty acids, iridoids, triterpenes, saponins, polysaccharides, essential oils, tannins, phytoecdisteroids and mucilages [37].

$$
\text { EU, HF, MA, } 5
$$

$\mathrm{ME}$

\author{
EU, IF, ME 2
}

3

(1)

\author{
Antiinflammatory, \\ antirheumatic, cancer, \\ demulcent, diaphoretic, \\ diuretic, emetic, emollient, \\ expectorant, homeopathic, \\ laxative, purgative. \\ Antiflatulent, \\ antispasmodic, astringent, \\ cancer, cholagogue, \\ depurative, diuretic, \\ expectorant, homeopathyc, \\ hypnotic, ophthalmic, \\ pectoral, resolving, \\ sedative, stiptic, tonic, \\ vasoconstrictor, vulnerary.
}

12. Pulmonaria Contains flavonoids, ascorbic and silicic acid, saponins,
officinalis $\mathrm{L}$.
tannins, carotene, allantoin, rutin and mucous membranes.
The plant also contains unsaturated pyrrolizidine alkaloids EU, ME $2 \quad 3$ 3 [38].

13. Sonchus Contains flavonoids, proanthocyanids, saponins, alkaloids, oleraceus $L$.

fatty acids, vitamin C, carotenoids. Mineral elements:

AF, GS, HF, 2 sodium, potassium, calcium, magnesium, phosphorus, iron, copper, zinc, manganese [39].

14. Thymus Contains flavonoids, tannins, terpenoid compounds, serpyllum $\mathrm{L}$. volatile oil (containing mainly thymol, carvacrol, p-cimen, linalool, $\alpha$-pinene and other mono and sesquiterpenes ( $\beta$-caryophyllenes, germacren D or nerolidol), phenolic acids rosemary) and flavonoids (quercitin, eriocitrin, luteolin, apigenin, serpyllin) [40].

15. Arctium lappa Volatile oil, lignans, lactones, caffeic acid derivatives, $\mathrm{L}$. including chlorogenic acid, isochlorogenic acid, polysaccharides (fructose), mucilages (xyloglucans, xylanic acids), riterpenes: phytosterols and tannins [41].

16. Anethum Source of essential oils, proteins, fiber, fatty oil, graveolens L. carbohydrates and macroelements (calcium, potassium, magnesium, phosphorus, sodium), vitamin A and niacin [42].
Astringent, demulcent, diaphoretic, diuretic, emollient, expectorant, homeopathy, ophthalmic, resolving.

Cancer, emmenagogue, febrifuge, hepatic, hydrologist, poultice, tonic, warts.

Anthelmintic, antirheumatic, antiseptic, antispasmodic, carminative, deodorant, diaphoretic, disinfectant, expectorant, sedative, tonic.

Antibacterial, antifungal, antiphlogistic, antipsoriatic, aperient, blood purifier, carminative, cholagogue, depurative, diaphoretic, diuretic, hypoglycemic, stomachic.

Anti Halitosis, aromatic, carminative, diuretic, galactogog, stimulant, stomachic.

Note: Animal Food (AF), Environmental Uses (EU), Fuels (FU), Gene Sources (GS), Human Food (HF), Invertebrate Food (IF), Medicines (ME), Social Uses (SU).

\subsubsection{Nutritional Value and Areas of Use of ESH}

In general, the consumption of ESH was and is justified not only by their availability and accessibility, but also due to the considerable intake of phytonutrients (Table 1). It has the potential to improve the quality of human life as well as food security. They are important locally and are adapted to unique climatic and environmental conditions.

A comparative analysis of the selected ESH told us that their domains and use 
were common for both the population of the Republic of Moldova and other people, while retaining certain distinctive features. In addition to human nutrition, they were also used in many other fields such as: animal nutrition, social field, environment, etc. For its therapeutic effects, all selected plants were and are used, more or less and for medicinal purposes. The PFAF database developed a scale from 1 to 5 to establish the rating of ESH use in human nutrition, medicine, etc. According to it, in human nutrition, the maximum score belonged to Rumex acetosa L., Urtica dioica L., Viola odorata L. (with a score of 5 points), followed by Cichorium intybus L., Portulaca oleracea L., Taraxacum officinale L, Thymus serpyllum L., Arctium lappa L. and Anethum graveolens L. (with a score of 4 points). The most optimal ratio between food and medicinal use belongs to Urtica dioica L., with a ratio of 5/5 (Table 1). And that was not surprising, because it had practically became a long tradition for young nettles to be picked for food at the end of winter. Even now, Urtica dioica L. remains one of the most well-known and widely used herbs in both human nutrition and medicine. It seems that ESHs have been and continue to be the usual components in the diets of many peoples. Moldovans' ESH consumption preferences do not differ significantly from other peoples. However, the study shows some peculiarities: consumption, in large quantities of Anethum graveolens, which is used not only for flavoring dishes but also as their main raw material (Table 2). Pies with Anethum graveolens, green onion, are known and appreciated. Another local artisanal specialty is alivanca with cheese and dill. Also, in spring, a salad is made from dill leaves, onions and tomato sauce. Dill is so popular that, from a spontaneous plant, as it once was, it has now become a garden crop and is present in every household.

The leaves of Tussilago farfara and Rumex acetosa L. were frequently used, but are still used today, for modeling sarmales [44]. Rumex acetosa L. is also the natural acidifier for spring green soups.

Papaver rhoeas $L$. seeds are widely used, sometimes being the only ingredient used as a filling for many pastries (buns or rolls without fermented dough-with poppy seed filling boiled in red wine, cakes, pies, biscuits, etc.).

In many regions of the Republic of Moldova, an artisanal recipe for biscuits (poppy cakes) is known, for which the poppy seeds are crushed by hand until poppy milk is obtained, with which the cakes are sprinkled in abundance.

Thymus serpyllum $\mathrm{L}$. is irreplaceable in the preparation of sour borscht (bors) which is a healthy liqueur obtained by fermenting wheat bran: a food that is trivial in appearance, but amazing in its qualities. Westerners do not know much about this natural preparation, but in post-Soviet countries, it is very popular due to its invigorating sour taste (which acidifies soups) and its healing properties, if consumed as such. Without thyme, it is not perceived the traditional Moldovan zeama-traditional Moldovan soup.

The analysis of the specialized literature on ESH consumption in the world showed that their culinary application in the Republic of Moldova can still be 
Table 2. Culinary use of ESHs in the Republic of Moldova.

\begin{tabular}{lll}
\hline Binomial name & Edible part Way/mode of ussage (in human nutrition) & $\begin{array}{l}\text { Culinary use of ESHs in the } \\
\text { Republic of Moldova }\end{array}$
\end{tabular}

Sources: [15] [17] [18]

(the results of the interview)

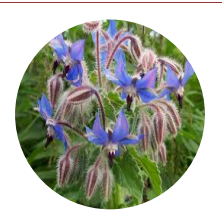

Borago officinalis L.
Flowers, Leaves: raw or cooked. They can be used as a potherb or be added leaves, oil to salads. They are also added whole as a flavoring to various drinks such as Pimms and wine-based drinks. The leaves have a salty cucumber flavor. The leaves should always be used fresh, because they lose their flavor and color if dried.

Flowers: raw. They are used as a decorative garnish on salads and summer fruit drinks. A refreshing tea is made from the leaves and/or the flowers. An edible blue dye can be obtained from the flowers. It is used to color vinegar.

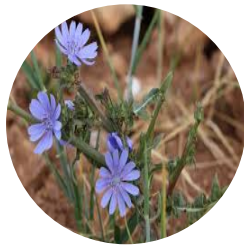

Cichorium intybus $\mathrm{L}$.
Flowers, leaves, roots

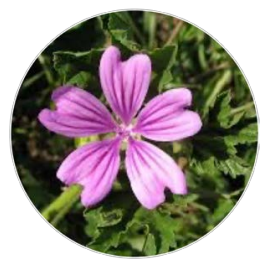

Malva sylvestris $\mathrm{L}$.

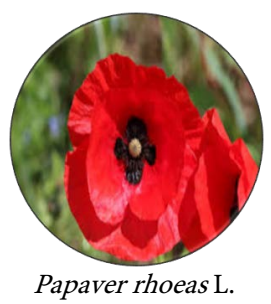
seeds
The leaves smell like cucumber, have a sweet-sour taste. Use young leaves that blush, then harden. They are made into soups-creams, sauces for noodles (noodles-fine pasta made of wheat flour and egg). The flowers: have a sweet taste and are used to decorate salads and desserts. In modern cuisine, flowers are used to make jams. The flowers of Borago officinali L. are also consumed in their natural state, mainly by children, absorbing the sweet nectar of the flowers.

In the diet of children in the form of tea.

Chicory root is used to abstain from a coffee-like drink [43].
Flowers, Seed: raw or cooked. Much used as a flavoring in cakes, bread, fruit leaves, oil, salads, etc., it imparts a very nice nutty flavor. The seeds are seeds perfectly safe to eat, containing none of the alkaloids associated with other parts of the plant.

Leaves: raw or cooked. Used like spinach or as a flavoring in soups and salads. The leaves should not be used after the flower buds have formed. Edible oil is obtained from the seed. Said to be an excellent substitute for olive oil, it can be used in salad dressings or for cooking. Syrup can be prepared from the scarlet flower petals, it is used in soups, gruels, etc. A red dye from the petals is used as a food flavoring, especially in wine [28].
Flowers, Leaves: raw or cooked. Mucilaginous with a mild pleasant flavor, leaves, they are nice in soups where they act as a thickener. The young flavor. Flowers: raw. Added to salads or used as a garnish. The leaves are a tea substitute.

Root: cooked like parsnip. The boiled young roots form a very because of its inulin content. Roots are used in seasoning soups, sauces and gravies, and to impart a rich deep color. The roasted root is used as a caffeine-free coffee adulterant or substitute. Young roots have a slightly bitter caramel flavor when roasted. they are nice in soups where they act as a thickener. The young
leaves also make a very acceptable substitute for lettuce in a salad. Immature seed: raw. Used as a nibble, the seeds have a nice nutty

The fresh or dehydrated and crushed plant is used in teas, infusions.

The leaves and flowers are used in salads. In some parts of MD they are used for sarmale.

The fruit, which has the shape of a coil or a cheese wheel, is a delight for children, eaten raw.

Poppy seeds are widely used, especially in pastries: as a filling for pies, rolled, for decoration. It is added to bakery products.

It is also added to salads, to meat products.

More recently, the use of leaves (raw but also cooked) has gained a new revival, being used in salads or vegetable stews. 


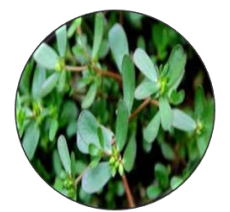

Portulaca oleracea L.

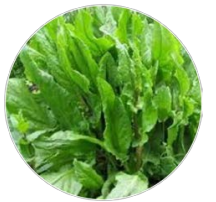

Rumex acetosa $\mathrm{L}$.
Leaves, Leaves and stems: raw or cooked. The young leaves are a very seeds acceptable addition to salads, their mucilaginous quality also making them a good substitute for okra as a thickener in soups. The leaves have a somewhat sour flavor, a spicy and somewhat salty eate taste.

Seed: raw or cooked. The seed can be ground into a powder and mixed with cereals for use in gruels, bread, pancakes etc.

Flowers, Curdling agent. Leaves: raw or cooked. They make a leaves, thirst-quenching on their own, or can be added to salads, used as a roots, seeds potherb or pureed, in sauces and used in soups. A delicious lemon-like flavor, liked by most people who try them, they can be rather overpowering in quantity and are more generally used as a flavoring in mixed salads. The leaves can also be dried for later use. The juice of the leaves can be used as a curdling agent for milks. Flowers: cooked as a vegetable or used as a garnish.

Root: cooked. It is dried, ground into a powder and made into noodles. Seed: raw or cooked. Ground into a powder and mixed with other flours to make bread.

Flowers, Leaves: raw or cooked. Tender young leaves are considerably less leaves, root bitter than older leaves. The leaves are often blanched (by excluding light from the growing plant) before use. Root: raw or cooked. Bitter. A turnip-like flavor. The roots of 2-year-old plants are harvested in the autumn, dried and roasted to make a very good coffee substitute. Flowers: raw or cooked. A rather bitter flavor, the unopened flower buds can be used in fritters and they can also be preserved in vinegar and used like capers. Both the leaves and the roots are used to flavor herbal beers and soft drinks. A pleasant tea is made from the flowers. They are also used to make wine. The leaves and the roots can also be used to make tea.

Leaves, oil Couloring, drinh, oil, curling agent

Young leaves: cooked as a potherb and added to soups etc. The young shoots harvested in the spring when $15-20 \mathrm{~cm}$ long complete with the underground stem are very nice. The plants are harvested commercially for extraction of the chlorophyll, which is used as a green coloring agent (E140) in foods and medicines. The juice of the leaves, or a decoction of the herb, can be used as a rennet substitute in curdling plant milks. Nettle beer is brewed from the young shoots [34].

Flowers, Flower buds and young flowers: raw or cooked. A pleasant aniseed leaves, oil flavor, they add a distinctive aromatic flavor to salads.

Young leaves: raw or cooked. They can be used in salads, added to soups, or cooked as a vegetable. The leaves have a bitter taste unless they are washed after being boiled. An aromatic tea is made from the fresh or dried leaves and flowers. It has a liquorice-like flavor. The dried and burnt leaves are used as a salt substitute. The slender rootstock is candied in sugar syrup.
The young leaves are used in salads, soups. As a food supplement: fresh leaves covered with bee honey are

The sauce is also prepared from the leaves, adding yogurt and cucumbers.

The leaves are widely used in soups (borscht), especially spring green borscht (prepared mainly from weeds). It is used, including as an acidifying agent for soups. The young and fresh leaves are used in salads, pie fillings, vegetable stews, sauces, sarmale.

The young dandelion leaves were and are used for salads, in omelettes. The boiled leaves are used in soups and broths, teas.

The flowers are used to make wine or jam, and the crushed and roasted root can be used to make an energizing infusion with an effect similar to black tea. It was consumed more widely during the war and after the war, when hunger was rampant. Now, the dandelion enjoys a new life, being more and more frequently used in the daily diet of Moldovans.

One of the best known and most used spontaneous plant.

Egg stew is most often made from the leaves of the young plant, but it is also used in the preparation of soups, omelets, meatballs, pie fillings, sauces, etc. Leaf teas are also made.

Currently the leaves are also used for risotti, tarts, smoothies, pesto.

The most well-known use is due to the leaves, for packing the găluci (rustic name of the current Moldovan sarmales or internationally known variant-dolma) [44]. 


\section{Continued}

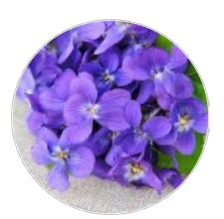

Viola odorata L.
Flowers, Young leaves and flower buds: raw or cooked. Usually available all leaves soon become quite tough as they grow older. They make a very good salad. When added to soup they thicken it in much the same way as okra. Also used as a flavoring in puddings etc. A tea can be made from the leaves.

Flowers: raw. Used to decorate salads and desserts. A sweet mild flavor with a delicate perfume, the flowers are an especially welcome decoration for the salad bowl since they are available in late winter. The flowers are also used fresh to flavor and color confectionery. A soothing tea can be made from the leaves and flowers. A leaf extract is used to flavor sweets, baked goods and ice cream.

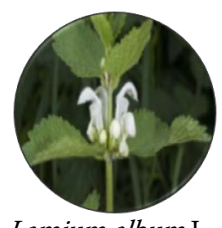

Leaves

Young leaves: raw or cooked. They can be added to salads or mixed
with other leaves and cooked as a potherb. They can also be dried for later use. A pleasant herb tea is made from the flowers.

Leaves

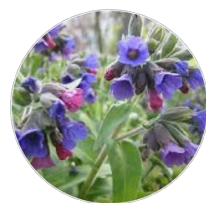

Pulmonaria officinalis $\mathrm{L}$.

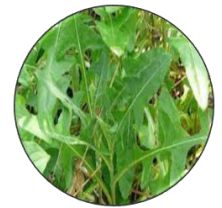

Leaves, roots,

stems

Sonchus oleraceus L.
Leaves: raw or cooked. They can be added to salads or used as a potherb. A fairly bland flavor but the leaves are low in fiber and make an acceptable addition to mixed salads, though their mucilaginous and slightly hairy texture make them less acceptable when eaten on their own. The young leaves make a palatable cooked vegetable, though we have found the texture to be somewhat slimy. The plant is an ingredient of the drink Vermouth.

Young leaves: raw or cooked. This species has the nicest tasting leaves of the genus, they usually have a mild agreeable flavor especially in the spring. They can be added to salads, cooked like spinach or used in soups etc. Stems: cooked like asparagus or rhubarb. They are best if the outer skin is removed first.

Young root: cooked. They are woody and not very acceptable. The milky sap has been used as a chewing gum by the Maoris of New Zealand.
Both flowers and leaves are used raw in salads, and flowers for decoration. From the fermented flowers, a slightly alcoholic, aromatic drink similar to cherry or socata is obtained.

The flowers are sugary and are used to decorate and flavor desserts.
Shoots, the top of the plant and the young leaves are used. Flowers: in salads, stews, omelettes. The flowers are often eaten by children, due to their sweet taste. Occasionally, it is also used in green sauces.

The flowers are eaten, which are a delight for children due to their sweet taste.
The young leaves are used in salads, soups (just like spinach). They were also used for pie fillers, colțunași. Colțunaşi-dough food, similar to Italian tortellini, with various fillings (cheese, greens, potatoes or cherries), boiled in water and served with sour cream or other dressing. The tender stems are also eaten raw.

Accompanied by a light rubbing between the palms, while a folk song was said: susai-susai, make yourself sweet that you cut yourself... After which the stem was given to the children to eat

Moldovans use thyme (both fresh and dehydrated), mainly for flavoring soups, and traditional Moldovan zeama.

Sour borş (borscht) is also flavored-A sour liqueur for acidifying soups, obtained from the fermentation of wheat bran. It is also used to flavor iron wine, oil or vinegar. Inflorescences, stems and leaves are used to make tea. 


\section{Continued}

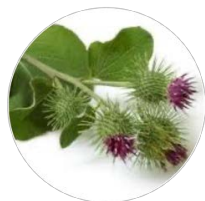
root, seeds, roots are normally cooked. Although it does not have much flavor stem

Arctium lappa L.

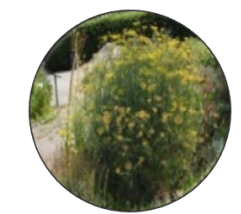

Leaves,

seeds

Anethum graveolens L. but this becomes stronger as the root gets older.

Young leaves: raw or cooked. A mucilaginous texture.

Young stalks and branches: raw or cooked. Used like asparagus or spinach. They taste best if the rind is removed. The leaf stalks can be parboiled and used as a substitute for cardoons. The pith of the flowering stem can be eaten raw in salads, boiled or made into confections. A delicate vegetable, somewhat like asparagus in flavor. The seeds can be sprouted and used like beansprouts.

Leaves: raw or cooked. Used as a flavoring in salads etc. The leaves lose their flavor if they are cooked for any length of time and so are best used raw or added to cooked dishes only a few minutes before the cooking is complete. The leaves can be harvested at any time the plant is growing but are best just before the plant flowers. Seed: raw or cooked. Very pungent and bitter in taste. It is used as a flavoring in salads, preserves etc., its chief uses being perhaps in making dill vinegar and as a flavoring in pickled gherkins. It can also be sprouted and used in breads, soups and salad dressings. Essential oil from the seed is used as a flavoring in the food industry. A tea is made from the leaves and/or the seeds.
Young stems are eaten sauteed or fried, but also raw (when young and tender). Young shoots are consumed in the same way as asparagus. The leaves are also used to shape sarmales.

The cleaned roots are also eaten, either heat-treated or raw, because they are crispy and sweet. However, the consumption of burdock on the territory of the Republic of Moldova is quite limited.

Dill leaves, stems and seeds are used. Dill leaves are used in soups, stews, traditional products, salads, pie fillings.

The leaves, stem and inflorescences are used to flavor pickles, canned food for the winter. Store pickled, salted, frozen or dehydrated.

Dill is also used to make tea or flavor the oil.

diversified. Some of their properties, after further studies, could possibly be used in the design of new products for people with special diets (hypoglycemic diet, gluten-free diet, etc.) or the improvement of those diets [45].

Knowledge and capitalization of ESH could also be an effective measure to prevent the disappearance of local food cultures and traditions, contributing to raising awareness of food security, perceived as quality, variety and access to food, with a commitment to consumers, producers, cultural diversity and the environment.

\section{Funding}

This research was funded by State Project "Personalized nutrition and intelligent technologies for my well-being”, grant number 20.80009.5107.10, running at Technical University of Moldova https://utm.md/.

\section{Conflicts of Interest}

The authors declare no conflicts of interest regarding the publication of this paper.

\section{References}

[1] Béné, C., Oosterveer, P., Lamotte, L., et al. (2019) When Food Systems Meet Sustainability-Current Narratives and Implications for Actions. World Development, 113, 116-130. https://doi.org/10.1016/j.worlddev.2018.08.011

[2] Willett, W., Rockström, J., Loken, B., et al. (2019) Food in the Anthropocene: The 
EAT-Lancet Commission on Healthy Diets from Sustainable Food Systems. The Lancet, 393, 447-492. https://doi.org/10.1016/S0140-6736(18)31788-4

[3] Ulian, T., Diazgranados, M., Pironon, S., et al. (2020) Unlocking Plant Resources to Support Food Security and Promote Sustainable Agriculture. Plants People Planet, 2, 421-445. https://doi.org/10.1002/ppp3.10145

[4] Díaz, S., Zafra-Calvo, N., Purvis, A., et al. (2020) Set Ambitious Goals for Biodiversity and Sustainability. Science, 370, 411-413. https://doi.org/10.1126/science.abe1530

[5] FAO, Commission on Genetic Resources for Food and Agriculture (2019) The State of the World's Biodiversity for Food and Agriculture.

[6] Li, X., Siddique, K.H.M. and Food and Agriculture Organization of the United Nations (2018) Future Smart Food: Rediscovering Hidden Treasures of Neglected and Underutilized Species for Zero Hunger in Asia. https://doi.org/10.18356/23b5f7ab-en

[7] Corlett, R.T. (2016) Restoration, Reintroduction, and Rewilding in a Changing World. Trends in Ecology \& Evolution, 31, 453-462. https://doi.org/10.1016/j.tree.2016.02.017

[8] Ranfa, A., Orlandi, F., Maurizi, A. and Bodesmo, M. (2015) Ethnobotanical Knowledge and Nutritional Properties of Two Edible Wild Plants from Central Italy: Tordylium apulum L. and Urospermum dalechampii (L.) F.W. Schmid. Journal of Applied Botany and Food Quality, 88, 249-254.

[9] Maurizi, A., De Michele, A., Ranfa, A., et al. (2015) Bioactive Compounds and Antioxidant Characterization of Three Edible Wild Plants Traditionally Consumed in the Umbria Region (Central Italy): Bunias erucago L. (Corn Rocket), Lactuca perennis L. (Mountain Lettuce) and Papaver rhoeas L. (Poppy). Journal of Applied Botany and Food Quality, 88, 109-114.

[10] Manach, C., Williamson, G., Morand, C., et al. (2005) Bioavailability and Bioefficacy of Polyphenols in Humans. I. Review of 97 Bioavailability Studies. The American Journal of Clinical Nutrition, 81, 230S-242S. https://doi.org/10.1093/ajcn/81.1.230S

[11] Pieroni, A., Nebel, S., Santoro, R.F. and Heinrich, M. (2005) Food for Two Seasons: Culinary Uses of Non-Cultivated Local Vegetables and Mushrooms in a South Italian Village. International Journal of Food Sciences and Nutrition, 56, 245-272. https://doi.org/10.1080/09637480500146564

[12] Vanzani, P., Rossetto, M., De Marco, V., et al. (2011) Efficiency and Capacity of Antioxidant Rich Foods in Trapping Peroxyl Radicals: A Full Evaluation of Radical Scavenging Activity. Food Research International, 44, 269-275.

https://doi.org/10.1016/j.foodres.2010.10.022

[13] Siminiuc, R. and Turcanu, D. (2020) The Impact of the Pandemic on the Agri-Food System. JSS, 3, 85-94.

[14] Schunko, C., Grasser, S. and Vogl, C.R. (2015) Explaining the Resurgent Popularity of the Wild: Motivations for Wild Plant Gathering in the Biosphere Reserve Grosses Walsertal, Austria. Journal of Ethnobiology and Ethnomedicine, 11, 55. https://doi.org/10.1186/s13002-015-0032-4

[15] Plant for a Future (PFAF). Database.

[16] U.S. Department of Agriculture Dr. Duke's Phytochemical and Ethnobotanical Databases.

[17] Diazgranados, M., Allkin, B., Black, N., et al. (2020) World Checklist of Useful Plant Species. 
[18] Plant of the World Online.

[19] Andrei, N. (2007) Determinator de plante din flora Republicii Moldova. Editura Universul, Moldova.

[20] Anatol, T,. (2016) Înfometarea Moldovei postbelice sub regimul sovietic (1946-1947). Akademos Istorie și Arheologie, 2, 117-125.

[21] Delang, C.O. (2006) The Role of Wild Food Plants in Poverty Alleviation and Biodiversity Conservation in Tropical Countries. Progress in Development Studies, 6, 275-286. https://doi.org/10.1191/1464993406ps143oa

[22] Mongkhonsin, B., Nakbanpote, W., Meesungnoen, O. and Prasad, M.N.V. (2019) Adaptive and Tolerance Mechanisms in Herbaceous Plants Exposed to Cadmium. In: Cadmium Toxicity and Tolerance in Plants, Elsevier, Amsterdam, 73-109. https://doi.org/10.1016/B978-0-12-814864-8.00004-8

[23] Donaldson, L., Nanayakkara, B. and Harrington, J. (2017) Wood Growth and Development. In: Encyclopedia of Applied Plant Sciences, Elsevier, Amsterdam, 203-210. https://doi.org/10.1016/B978-0-12-394807-6.00114-3

[24] Zemmouri, H., Ammar, S., Boumendjel, A., et al. (2019) Chemical Composition and Antioxidant Activity of Borago officinalis L. Leaf Extract Growing in Algeria. Arabian Journal of Chemistry, 12, 1954-1963. https://doi.org/10.1016/j.arabjc.2014.11.059

[25] Asadi-Samani, M., Bahmani, M. and Rafieian-Kopaei, M. (2014) The Chemical Composition, Botanical Characteristic and Biological Activities of Borago officinalis: A Review. Asian Pacific Journal of Tropical Medicine, 7, S22-S28. https://doi.org/10.1016/S1995-7645(14)60199-1

[26] Jancic, D., Todorovic, V., Basic, Z. and Sobajic, S. (2016) Chemical Composition and Nutritive Potential of Cichorium intybus L. Leaves from Montenegro. Journal of the Serbian Chemical Society, 81, 1141-1149. https://doi.org/10.2298/JSC160313057S

[27] Zohra, S.F., Meriem, B. and Samira, S. (2013) Some Extracts of Mallow Plant and Its Role in Health. APCBEE Procedia, 5, 546-550. https://doi.org/10.1016/j.apcbee.2013.05.091

[28] Grauso, L., de Falco, B., Motti, R. and Lanzotti, V. (2021) Corn Poppy, Papaver rhoeas L.: A Critical Review of Its Botany, Phytochemistry and Pharmacology. Phytochemistry Reviews, 20, 227-248. https://doi.org/10.1007/s11101-020-09676-7

[29] Petropoulos, S.A., Fernandes, Â., Dias, M.I., et al. (2019) Nutritional Value, Chemical Composition and Cytotoxic Properties of Common Purslane (Portulaca oleracea L.) in Relation to Harvesting Stage and Plant Part. Antioxidants, 8, 293. https://doi.org/10.3390/antiox8080293

[30] Stopps, G., White, S., Clements, D. and Upadhyaya, M. (2011) The Biology of Canadian Weeds. 149. Rumex acetosella L. Canadian Journal of Plant Science, 91, 1037-1052. https://doi.org/10.4141/cjps2011-042

[31] Ceccanti, C., Landi, M., Incrocci, L., et al. (2020) Comparison of Three Domestications and Wild-Harvested Plants for Nutraceutical Properties and Sensory Profiles in Five Wild Edible Herbs: Is Domestication Possible? Foods, 9, 1065. https://doi.org/10.3390/foods9081065

[32] Escudero, N.L., De Arellano, M.L., Fernández, S., et al. (2003) Taraxacum officinale as a Food Source. Plant Foods for Human Nutrition, 58, 1-10. https://doi.org/10.1023/B:QUAL.0000040365.90180.b3 
[33] Dias, M.I., Barros, L., Alves, R.C., et al. (2014) Nutritional Composition, Antioxidant Activity and Phenolic Compounds of Wild Taraxacum sect. ruderalia. Food Research International, 56, 266-271. https://doi.org/10.1016/j.foodres.2014.01.003

[34] Jan, K.N., Zarafshan, K. and Singh, S. (2017) Stinging Nettle (Urtica dioica L.): A Reservoir of Nutrition and Bioactive Components with Great Functional Potential. Food Measure, 11, 423-433. https://doi.org/10.1007/s11694-016-9410-4

[35] Chromchenkova, E.P., et al. (2020) Coltsfoot Leaves (Tussilago farfara L.) - A Promising Source of Essential Amino Acids. Systematic Reviews in Pharmacy, 6, 221-225.

[36] Mittal, P., Gupta, V., Goswami, M., et al. (2015) Phytochemical and Pharmacological Potential of Viola odorata. International Journal of Pharmacognosy, 2, 215-220.

[37] Pourmirzaee Sheikhali Kelayeh, T., Abedinzade, M. and Ghorbani, A. (2019) A Review on Biological Effects of Lamium album (White Dead Nettle) and Its Components. Journal of Herbmed Pharmacology, 8, 185-193.

https://doi.org/10.15171/jhp.2019.28

[38] Dyshlyuk, L.S., Fedorova, A.M., Dolganyuk, V.F. and Prosekov, A.Y. (2020) Optimization of Extraction of Polyphenolic Compounds from Medicinal Lungwort (Pulmonaria officinalis L.). Journal of Pharmaceutical Research International, 32, 36-45. https://doi.org/10.9734/jpri/2020/v32i2430807

[39] Puri, A.V., Khandagale, P.D. and Ansari, Y.N. (2018) A Review on Ethnomedicinal, Pharmacological and Phytochemical Aspects of Sonchus oleraceus Linn. (Asteraceae). International Journal of Pharmacy and Biological Sciences, 8, 1-19.

[40] Wisam, S.U., Nahla, T.K. and Tariq, N.M. (2017) Antioxidant Activities of Thyme Extracts. Pakistan Journal of Nutrition, 17, 46-50. https://doi.org/10.3923/pjn.2018.46.50

[41] Skowrońska, W., Granica, S., Dziedzic, M., et al. (2021) Arctium lappa and Arctium tomentosum, Sources of Arctii radix: Comparison of Anti-Lipoxygenase and Antioxidant Activity as Well as the Chemical Composition of Extracts from Aerial Parts and from Roots. Plants, 10, 78. https://doi.org/10.3390/plants10010078

[42] Biesiada, A., Kędra, K., Godlewska, K., et al. (2019) Nutritional Value of Garden Dill (Anethum graveolens L.), Depending on Genotype. Notulae Botanicae Horti Agrobotanici Cluj-Napoca, 47, 784-791. https://doi.org/10.15835/nbha47311395

[43] Ciocârlan, N. (2014) Cicoarea-Un remediu ideal pentru sănătatea ta (Chicory-An Ideal Remedy for Your Health). Farmacia naturii Mediul ambient, 6, 39-40.

[44] Gutium, O., Siminiuc, R., Grosu, C. and Cazac, V. (2020) Sarmale-Symbol of Moldovan Gastronomy.

[45] Siminiuc, R. and Țurcanu, D. (2020) Certain Aspects of Nutritional Security of People with Gluten-Related Disorders. Food and Nutrition Sciences, 11, 1012-1031. https://doi.org/10.4236/fns.2020.1111072 